\title{
ERRATUM
}

Nathan A. Ellis $\cdot$ Susan Ciocci $\cdot$ James German

\section{Back mutation can produce phenotype reversion in Bloom syndrome somatic cells}

Published online: 23 May 2001

(C) Springer-Verlag 2001

\section{Hum Genet (2001) 108:167-173}

In the legend to Fig. 2, the BLM mutation in $86(\mathrm{NoKi})$ was erroneously identified as $B L M * 1514 i n s A$ (twice). The correct name of the mutation is $B L M * 1544$ insA.

The online version of the original article can be found at http://dx.doi.org/10.1007/s004390000447

N.A. Ellis $(\bowtie) \cdot$ S. Ciocci

Department of Human Genetics,

Box no. 124, Memorial Sloan-Kettering Cancer Center,

1275 York Avenue, New York, NY 10021, USA

e-mail: n-ellis@ski.mskcc.org,

Tel.: +1-212-6397183, Fax: +1-212-7173571

J. German

Department of Pediatrics, Cornell University Medical College,

New York, NY 10021, USA 